\title{
IMPROVEMENT OF SAFETY MEASURES BY APPLYING A TECHNICAL SOLUTION ON THE M-80A INFANTRY COMBAT VEHICLE
}

\author{
Milan N. Končar ${ }^{a}$, Odil I. Anarbaev ${ }^{b}$, Dobrivoje R. Mutavdžićc ${ }^{\text {, }}$ \\ Goran M. Lazićd, Željko M. Jokić \\ a University of Defense in Belgrade, Military Academy, \\ Department of Army Weapons and Equipment, \\ Belgrade, Republic of Serbia, \\ e-mail: liksko@gmail.com, corresponding author, \\ ORCID iD: Dhttps://orcid.org/0000-0002-8247-5397 \\ ${ }^{\mathrm{b}}$ Academy of the Armed Forces of the Republic of Uzbekistan, \\ Department of General Tactics, Tashkent, Republic of Uzbekistan, \\ e-mail: nusmonova516@gmail.com \\ ${ }^{c}$ University of Defense in Belgrade, Military Academy, \\ Department of Army Weapons and Equipment, \\ Belgrade, Republic of Serbia, \\ e-mail: undertakerxxx4@gmail.com, \\ ORCID iD: (iohttps://orcid.org/0000-0003-0961-4546 \\ d University of Defense in Belgrade, Military Academy, \\ Department of Army Weapons and Equipment, \\ Belgrade, Republic of Serbia, \\ e-mail: goran.lazic@va.mod.gov.rs, \\ ORCID iD: (Dhttps://orcid.org/0000-0001-9752-3956 \\ e University of Defense in Belgrade, Military Academy, \\ Department of Army Weapons and Equipment, \\ Belgrade, Republic of Serbia, \\ e-mail: antras1209@gmail.com, \\ ORCID iD: Dhttps://orcid.org/0000-0002-3646-1787
}

DOI: 10.5937/vojtehg69-31837; https://doi.org/10.5937/vojtehg69-31837

FIELD: Mechanical engineering, Weapons ARTICLE TYPE: Original scientific paper

\begin{abstract}
:
Introduction/purpose: The paper presents a solution for overcoming a possible problem - breach of safety measures when operating the BVP M$80 \mathrm{~A}$ Infantry Combat Vehicle on a training ground during tactical exercises and shooting at night. The crux of the problem is that the officer in charge of a tactical exercise and shooting is not in a position to observe in which direction the gunner-operator aims because no device has been installed on the BVP M-80A to signal this.
\end{abstract}


Methods: After deploying the vehicle in practice and and on the basis of experience during shooting, it was concluded that there is a problem of controlling shooting at night and in reduced visibility conditions.

Results: The paper provides a practical solution to prevent situations such as disorientation, impossibility of observing targets, and turning weapons towards the outside the shooting range boundaries, thus violating the security measures of all participants in the exercise including the BVP M$80 A$ unit itself. A technical improvement was implemented on the vehicle by installing a signaling device that gives visual information to the officer in charge of shooting in which direction the weapon is turned.

Conclusion: The installed signaling device enables the officer who commands the exercise and shooting to be in control in a timely manner, eliminate possible causes of violation of security measures, and successfully implement the planned activity.

Keywords: security measures, control, combat vehicle, technical improvement, signaling device.

\section{Solution applied to improve safety measures}

This technical solution belongs to the domain of armored vehicle constructions and has multiple applications. The construction and installation of the signalizer ensure that the officer who commands the tactical exercise and shooting has control over the operation of the BVP $\mathrm{M}-80 \mathrm{~A}$ unit at distances of over $600 \mathrm{~m}$. The application of this technical improvement allows complete implementation and respect of safety measures during tactical live-fire exercises at night. In addition to the construction and installation of the signaling device, the construction of additional lighting is also planned with the aim of preparing weapons and ammunition for exercises at night or in reduced visibility conditions. (Školski centar oklopno-mehanizovanih jedinica JNA, 1990)

Construction defect to be corrected by applying this technical solution - improvement

The BVP M-80A is not equipped with a signaling device that provides visual information in which direction the weapon is directed (Savezni sekretarijat za narodnu odbranu, 1988a) unlike the M-84 tank where the headlight is installed on the turret (Novinsko-izdavačka ustanova „Vojska“, 1995). The BVP M-80A is armed with a $20 \mathrm{~mm}$ cannon and a $7.62 \mathrm{~mm}$ machine gun (Savezni sekretarijat za narodnu odbranu, 1988b). The officer in charge of a tactical exercise or shooting 
is not able to exercise control over the operation of mechanized units in conditions of reduced visibility (rain, fog, snow, etc.) or at night.

\section{Construction defect}

The curricula of specialised classes for cadets of the Military Academy and reserve officer training course, armored units, prescribe both day and night-time shooting on the automated shooting range.

On the Orešac automated shooting range (ASR), the track for armored vehicles is about $600 \mathrm{~m}$ long. At the end of the track, there is space for turning armored vehicles after shooting has ended. At the command of the officer in charge, the driver starts turning the armored vehicle in order to get back to the starting line and during the turn the weapon should aim at the targets in order not to violate safety measures. At all times, the shooting commander should know/have visual control of the direction the weapon is facing (Školski centar oklopnomehanizovanih jedinica JNA, 1990). Due to the fact that the BVP M-80A is not equipped with a visual signaling device, the tactical exercise or shooting commander cannot fully control the operation of the mechanized unit crew (Generalštab Vojske Jugoslavije, 1998).

The construction and installation of a signaling device on the BVP $\mathrm{M}-80 \mathrm{~A}$ turret solved the problem of observing in which direction vehicle weapons are positioned. In this way, security was improved during activities at night or in conditions of reduced visibility. In addition to the mentioned signaling device, an additional light should be installed to illuminate the turret during the weapon and ammunition preparation (Končar et al, 2016).

During tactical exercises and shooting at night and in reduced visibility conditions, the lecturers at the armored unit training course used the mentioned device and as such it proved to be effective and the security measures were raised to a higher level. There was no engagement in the armored units of the Serbian Army to find a solution to the problem. The explanation given is that, during tactical and shooting exercises, vehicles are occupied by commanders of mechanized units, trained to successfully realize all tasks. However, it is clear that the officer in charge of the exercise still has no control over the activities of the gunner-operator of a mechanized unit.

\section{Description of the technical solution}

The BVP M-80A signaling device with additional light is the result of many years of experience of the Military Academy officers, gained in the 
realization of shooting training by armored units. This structural element of the BVP M-80A is intended for shooting at night and in conditions of reduced visibility on the automated shooting range of armored units.

The main parts are:

- signaling device,

- distributors with switches and sockets,

- electrical installation kit, and

- extra light.

The parts are structurally adapted to be easy to install and to be operated easily and safely.

Installation:

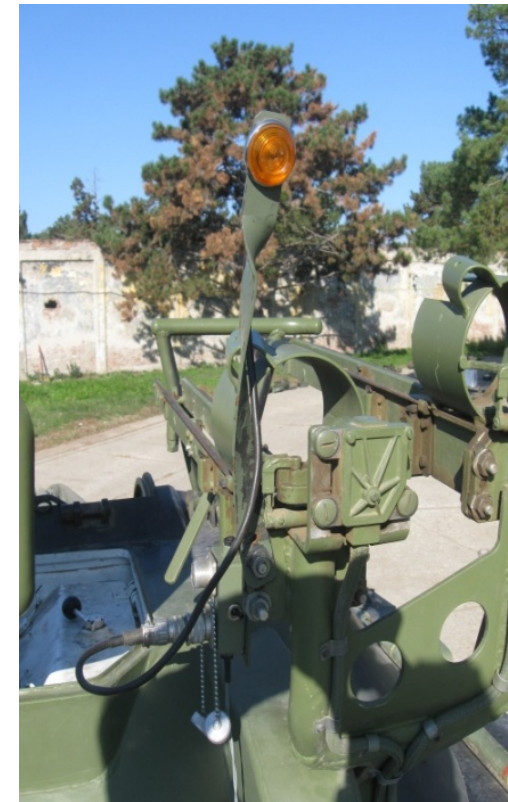

a)

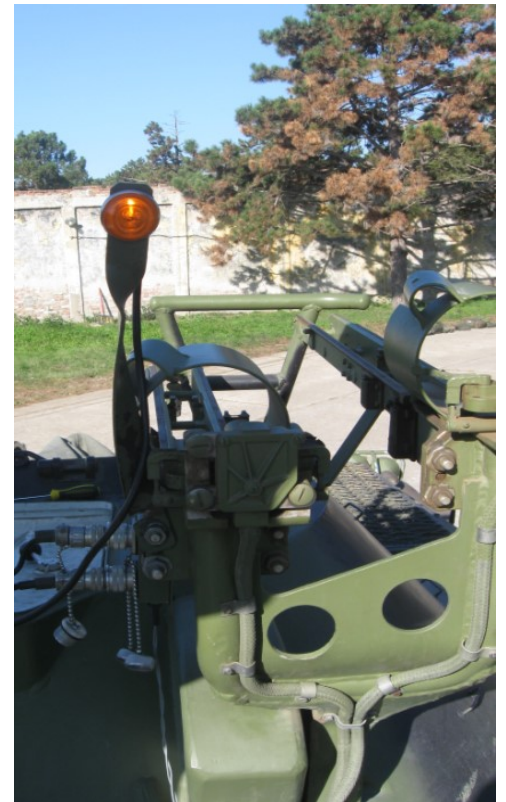

b)

Figure 1 - Signalizer with the mount

Puс. 1 - Сигнализатор с креплением

Слика 1 - Сигнализатор са постољем

In Figure 1a, there is a signaling device on the stand and with a conductor. Figure 1a shows the situation when the signaling device is switched off, and Figure 1b when the signaling device is switched on. The signaling stand is mounted on the launcher of the anti-tank guided 
missile and fixed with a screw without violating the purpose of the launcher (Savezni sekretarijat za narodnu odbranu, 1988c).

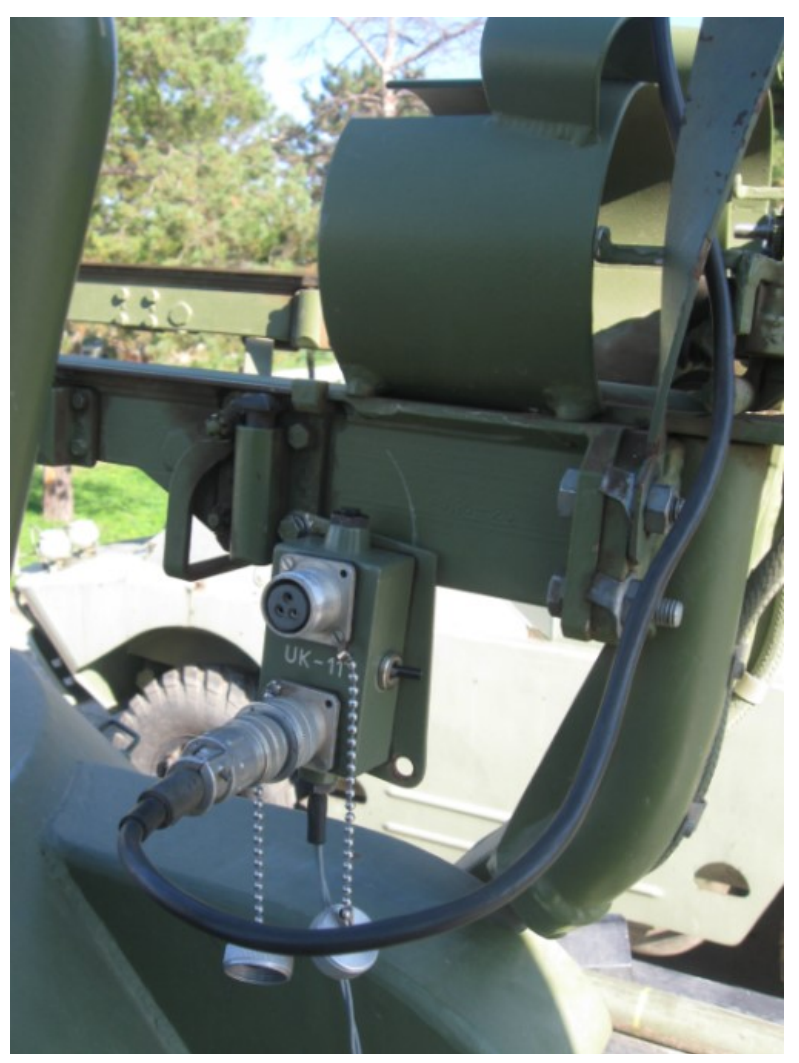

Figure 2 - Distributor

Pис. 2 - Распределитель

Слика 2 - Разводник

The signaling device is connected to the distributor by a three-pole contact. The distributor is installed on the anti-tank guided missile launcher and secured so that it does not obstruct the launcher operation. There are two three-pole sockets on the distributor.

The three-pole contact of the signaling device is connected to the lower socket while the three-pole contact of the additional light is connected to the upper socket.

A switch intended for switching on the additional light is installed on the distributor (Figures $3 a$ and $3 b$ ). 


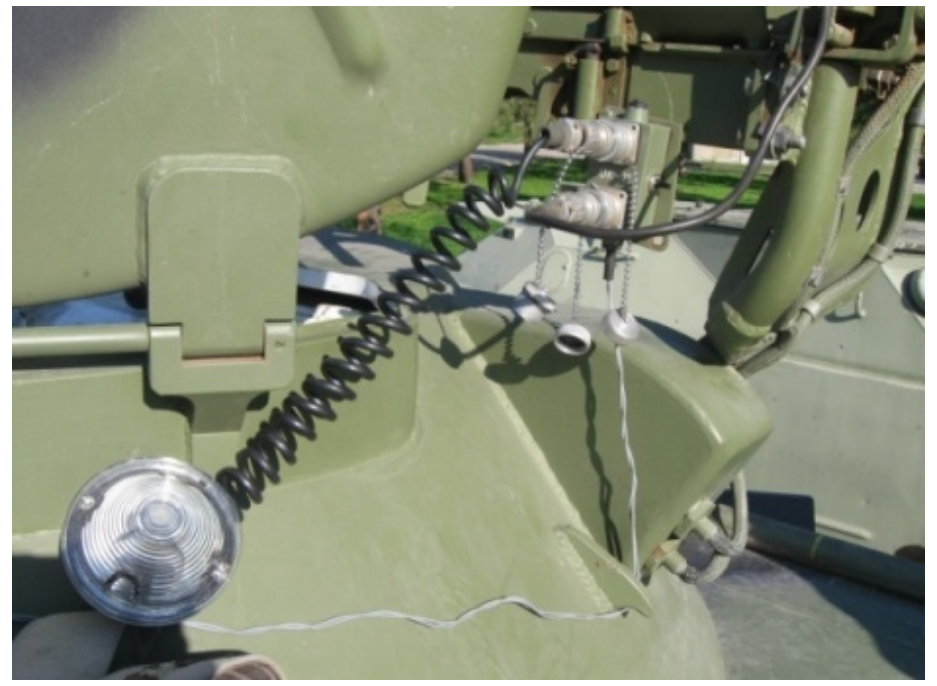

年

Puc. За - Дополнительное освещение - выкл.

Слика За - Додатно светло - искључено

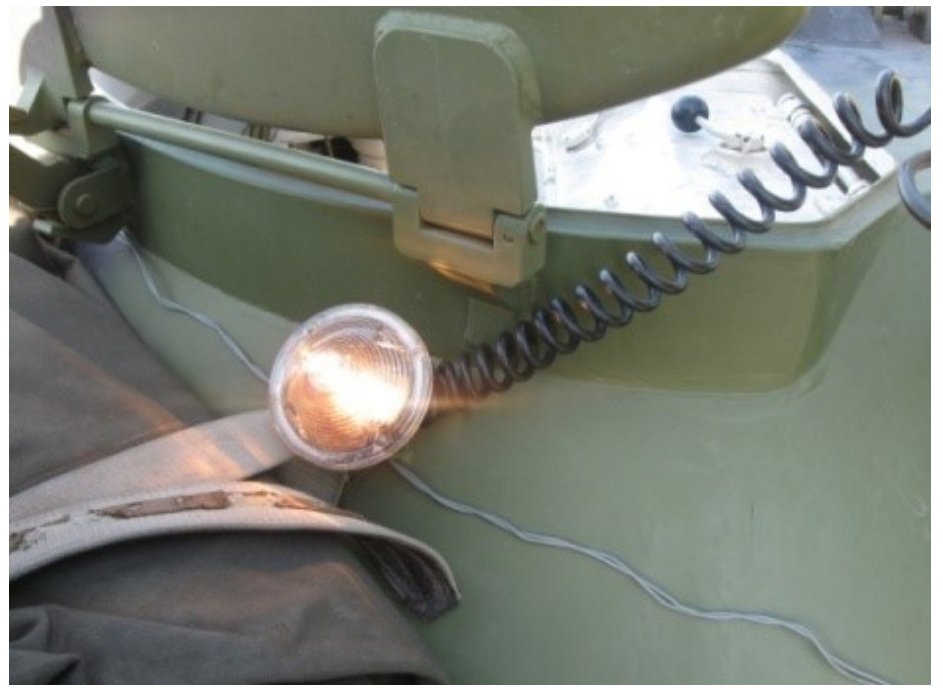

Figure $3 b-$ Additional light - on

Pис. 36 - Дополнительное освещение - вкл.

Слика Зб - Додатно светло - укључено

A common conducting wire connects all parts in the circuit. 


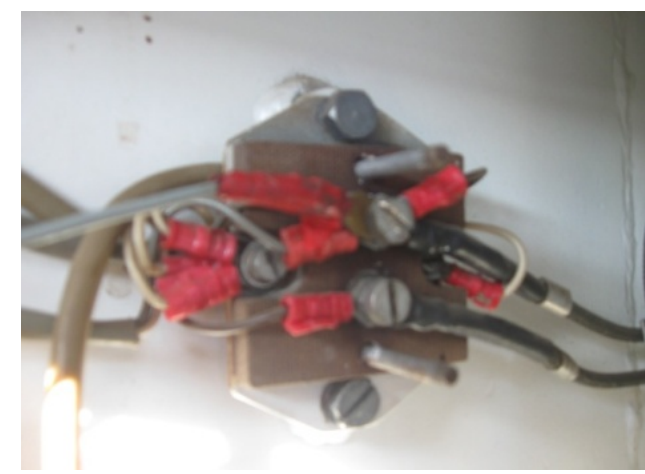

Figure $4-"+"$ pole

Puс. 4 - „"“ полюс

Слика $4-$ „+ "пол

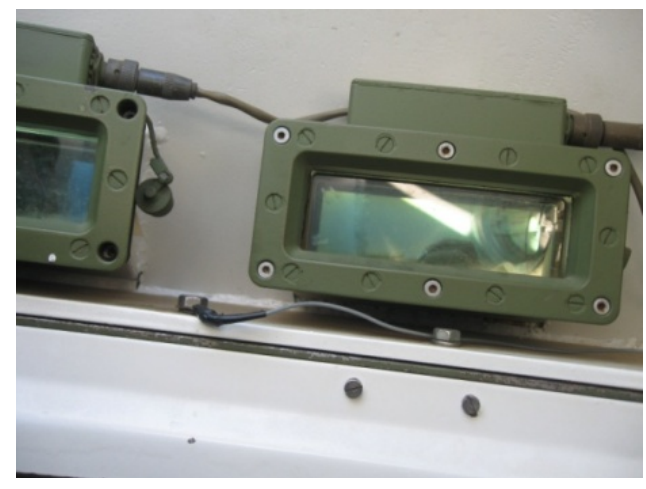

Figure 5 - "-" pole

Puc. 5- „“" полюс

Слика 5 - „-" пол

The " + " pole conductor is placed and fastened to the distribution box intended for the installation of the periscope heater for a gunner operator, Figure 4a (Savezni sekretarijat za narodnu odbranu, 1988a). The "-" pole conductor is placed on the turret edge (Figure 5).

The signalizer and the additional light are switched on in the following order:

- set the "ground" switch to the upper position (Figure 6). 


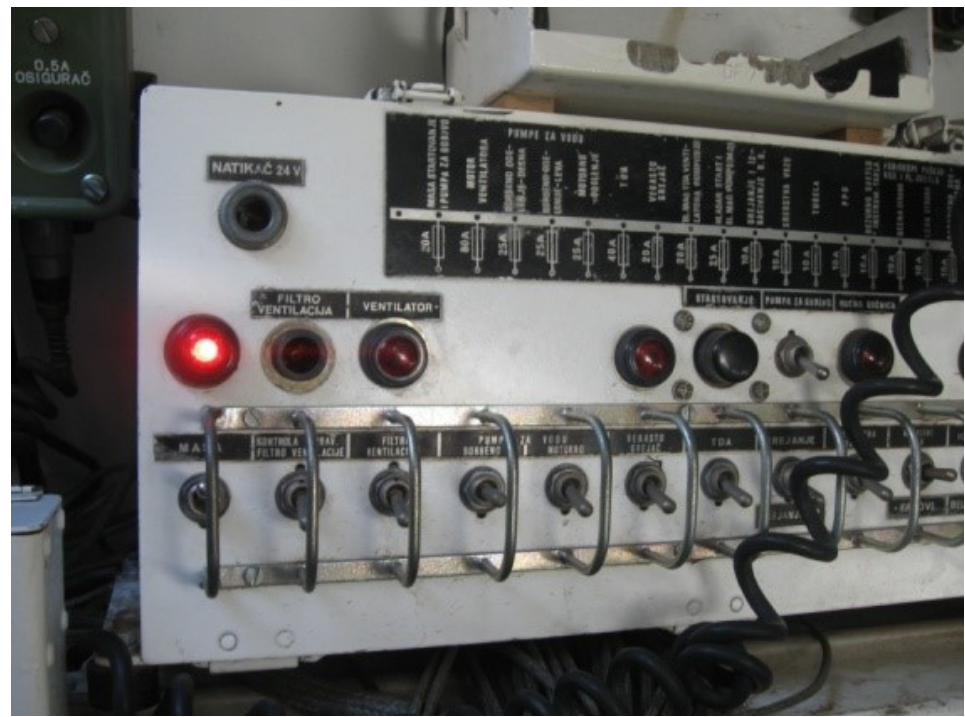

要

Figure 6 - Control panel in the BVP M-80A control section

Puc. 6 - Панель управления в секции управления БВП М-80A

Слика 6 - Контролна табла у управном одељењу БВП М-80А

- set the gunner's periscope heater switch to the upper position (ON), Figure 7 (Končar \& Isailović, 2009).

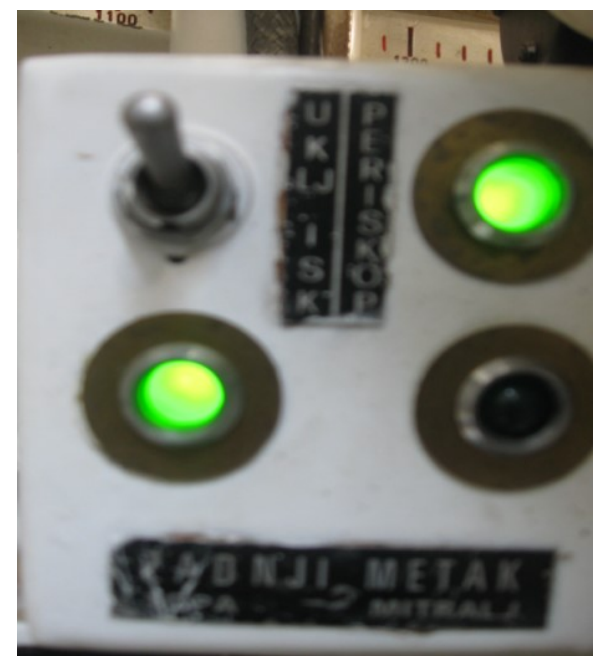

Figure 7-Gunner's periscope heater switch

Puc. 7 - Выключатель обогревателя перископа наводчика Слика 7 - Прекидач грејача перископа нишанције

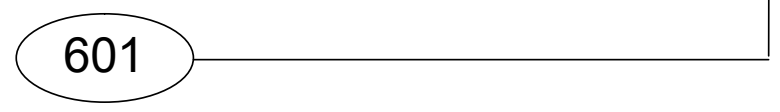


Figure 8 shows the BVP M-80A with the signalizer installed and swithed on just before the start of shooting on the automated shooting range.

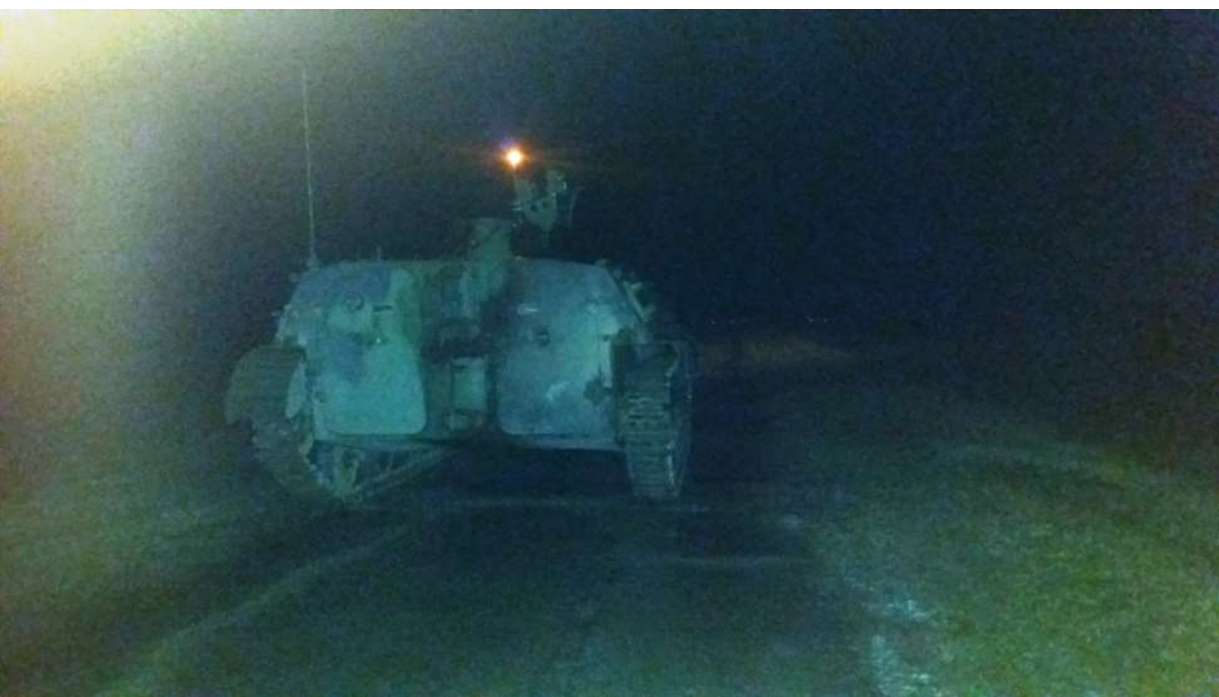

Figure $8-B V P M-80 A$ at the starting line

Puc. 8 - БВП М-80А на стартовой точке

Слика 8 - БВП М-80А на полазној линији

Figure 9 shows the BVP M-80A with the signaling device installed and switched on while moving during a night shooting exercise.

The signaling device is clearly visible, sending visual information that the weapon barrel is facing the target. In case that the signal light is not visible, shooting is stopped, the brake is used, and the weapon barrel is directed towards the target(s)(Školski centar oklopno-mehanizovanih jedinica JNA, 1990).

When the signal light is spotted again, shooting continues. In the situation when there is a fault on the signaling device, shooting is stopped until the fault is repaired by an electrical mechanic. 


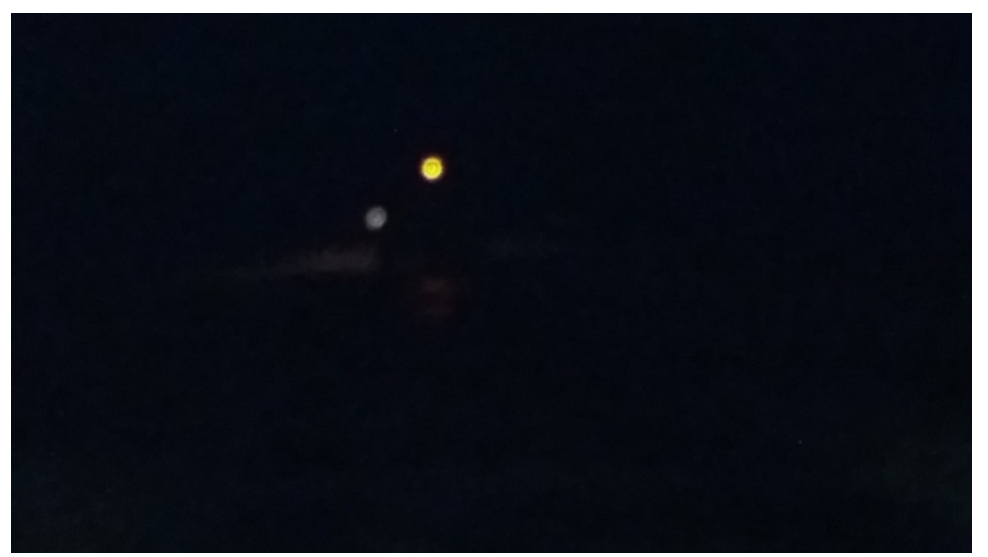

Figure $9-B V P M-80 A$ firing on the move on the track of the automated shooting range Puс. 9 - БВП М-80A ведет стрельбу с ходу по трассе автоматизированного стрельбища

Слика 9 - БВП М-80А на стази аутоматизованог стрелишта током кретања реализације гађања

\section{Conclusion}

The construction and installation of a signalizer enable a commanding officer in charge of the tactical exercise and shooting to completely control the operation of a mechanized unit at night and in conditions of reduced visibility. Security measures are fully complied with owing to this technical improvement. The construction and installation of an additional light to illuminate the turret enable the gunner-operator to have improved conditions for the weapon and ammunition preparation as well as for eliminating malfunctions and controlling the weapon unloading after the end of shooting.

\section{References}

-Generalštab Vojske Jugoslavije. 1998. Pravilo gađanja naoružanjem OMJ. Belgrade: Generalštab Vojske Jugoslavije (in Serbian).

Končar, M. \& Isailović, M. 2009. Naoružanje i oprema BVP M-80A, priručnik. Belgrade: Military Academy (in Serbian).

Končar, M., Mutavdžić, D. \& Nikolić, B. 2016. Lighting set tiles infantry fighting vehicle M-80A. In: II International scientific conference safety and crisis management - theory and practise safety for the future, Belgrade, pp.96-100, September 29-30 [online]. Available at: https://bekmen.rs/zbornik/2016/2016Zbornik-SRP.pdf (in Serbian) [Accessed: 9 April 2021]. ISBN: 978-86-80698-01-4. 
-Novinsko-izdavačka ustanova „Vojska“. 1995. Uputstvo i program gađanja naoružanjem oklopnih i mehanizovanih jedinica. Belgrade: Novinsko-izdavačka ustanova "Vojska“ (in Serbian).

-Savezni sekretarijat za narodnu odbranu (SSNO). 1988a. Tehničko uputstvo za BVP M-80 i M-80A: Opis, rukovanje, osnovno i tehničko održavanje - knjiga. Belgrade: Savezni sekretarijat za narodnu odbranu (SSNO) (in Serbian).

-Savezni sekretarijat za narodnu odbranu (SSNO). 1988b. Borbeno vozilo pešadije M-80 i M-80A: Priručnik za vojnika. Belgrade: Savezni sekretarijat za narodnu odbranu (SSNO) (in Serbian).

-Savezni sekretarijat za narodnu odbranu (SSNO). 1988c. Tenk M-84: Opis, rukovanje, osnovno i tehničko održavanje - knjiga 2. Belgrade: Savezni sekretarijat za narodnu odbranu (SSNO) (in Serbian).

-Školski centar oklopno-mehanizovanih jedinica JNA. 1990. Naoružanje BVP M-80A: Priručnik za pitomce. Banja Luka: Školski centar oklopnomehanizovanih jedinica JNA (in Serbian).

\section{УЛУЧШЕНИЕ МЕР БЕЗОПАСНОСТИ ПУТЕМ ПРИМЕНЕНИЯ ТЕХНИЧЕСКОГО РЕШЕНИЯ НА СУХОПУТНОЙ БОЕВОЙ МАШИНЕ М-80А}

Милан Н. Кончар ${ }^{\text {, }}$ корреспондент, Одил И. Анарбаев ${ }^{6}$, Добривое Р. Мутавджич ${ }^{\mathrm{B}}$, Горан М. Лазич ${ }^{\Gamma}$, Желько М. Йокич"

а Университет обороны в г. Белград, Военная академия, кафедра вооружения и техники сухопутных войск, г. Белград, Республика Сербия

${ }^{\sigma}$ Академиия Вооружённых сил Республики Узбекистан, кафедра общей тактики, г. Ташкент, Республика Узбекистан

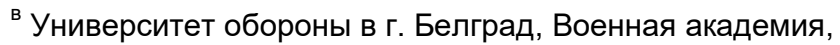
кафедра вооружения и техники сухопутных войск, г. Белград, Республика Сербия

' Университет обороны в г. Белград, Военная академия, кафедра вооружения и техники сухопутных войск, г. Белград, Республика Сербия

д Университет обороны в г. Белград, Военная академия, кафедра вооружения и техники сухопутных войск, г. Белград, Республика Сербия

РУБРИКА ГРНТИ: 78.00.00 ВОЕННОЕ ДЕЛО:

78.25.00 Вооружение и военная техника; 78.25.10 Бронетанковая техника

ВИД СТАТЬИ: оригинальная научная статья

Резюме:

Введение/цель: В данной статье представлено решение по преодолению возможной проблемы - нарушения техники 
безопасности при эксплуатации боевой сухопутной машины БВП M-80A на полигоне во время ночных тактических учений и стрельбы. Суть проблемы заключается в том, что командир, отвечающий за тактические учения и управление огнем, не может отслеживать за направлением прицела наводчикаоператора, так как на БВП М-80A не было установлено устройство, сигнализирующее о наводке.

Методы: После практического применения боевой машины и на основании опыта во время стрельбы был сделан вывод, что существует проблема управления огнем ночью и в условиях ограниченной видимости.

Результаты: В статье предложено практическое решение по предотвращению таких ситуаций, как дезориентация, невозможность прицела и поворот вооружения за пределы зоны огня, что нарушает меры безопасности всех участников учений, в том числе и самой боевой машины БВП М-80А. На машине была произведена техническая доработка за счет установки сигнального устройства, которое дает визуальную инфрормацию командиру, руководящему стрельбой, который с ее помощью владеет инфрормацией в каком направлении нацелено танковое вооружение.

Выводы: Установленное сигнальное устройство позволяет оперативно руководить учениями и стрельбой, устранять возможные причины нарушения мер безопасности и успешно выполнять запланированные действия.

Ключевые слова: меры безопаности, контроль, боевая машина, техническое развитие, сигнализатор.

ПОБОЉШАЊЕ МЕРА БЕЗБЕДНОСТИ ПРИМЕНОМ ТЕХНИЧКОГ РЕШЕЊА НА БОРБЕНОМ ВОЗИЛУ ПЕШАДИЈЕ М-8ОА

Милан Н. Кончар ${ }^{a}$, аутор за преписку, Одил И. Анарбаев ${ }^{6}$,

Добривоје Р. Мутавџић ${ }^{\mathrm{B}}$, Горан М. Лазић ${ }^{\Gamma}$, Жељко М. Јокић

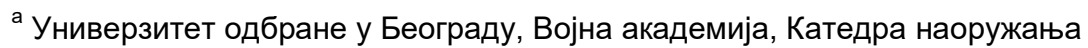
и опреме Копнене војске, Београд, Република Србија

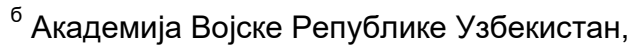
Катедра за општу тактику, Ташкент, Република Узбекистан

${ }^{\text {в } У н и в е р з и т е т ~ о д б р а н е ~ у ~ Б е о г р а д у, ~ В о ј н а ~ а к а д е м и ј а, ~ К а т е д р а ~ н а о р у ж а њ а ~}$ и опреме Копнене војске, Београд, Република Србија

г Универзитет одбране у Београду, Војна академија, Катедра наоружања и опреме Копнене војске, Београд, Република Србија

д Универзитет одбране у Београду, Војна академија, Катедра наоружања и опреме Копнене војске, Београд, Република Србија 
ОБЛАСТ: машинство, наоружање

ВРСТА ЧЛАНКА: оригинални научни рад

\section{Сажетак:}

Увод/циљ: У раду је приказан начин превазилажења могућег угрожавања мера безбедности приликом рада са борбеним возилом пешадије М-80А на полигонима приликом извођења тактичких вежби и гађања у ноћним условима. Суштина проблема је у томе да старешина који командује тактичким вежбама и гађањима не може да види у ком смеру нишани нишаниија-оператор, јер на БВП М-80А није уграђен уређај који би то сигнализирао.

Meтоде: На основу искуства приликом реализације гађања дошло се до закључка да извршилац гађања на овом возилуима проблем при контроли гађања ноћу и у условима отежане видљивости.

Резултати: У раду се предлаже практично решење проблема дезоријентације, немогућности осматрања мета и окретања наоружања ван граница поља гађања, а тиме и нарушавања мера безбедности свих учесника вежбе и извршилаца гађања и покретних средстава. Техничко унапређење на возилу остварено је уградњом сигнализатора који старешини који руководи гађањем даје визуелну информацију о смеру у којем је окренуто наоружање.

Закључак: Уградњом сигнализатора старешина који командује вежбом и гађањем правовремено може да оствари контролу, отклони могуће узроке нарушавања мера безбедности и успешно реализује планирану активност.

Кључне речи: мере безбедности, контрола, борбено возило, техничко унапређење, сигнализатор.

Paper received on / Дата получения работы / Датум пријема чланка: 14.04.2021.

Manuscript corrections submitted on / Дата получения исправленной версии работы / Датум достављања исправки рукописа: 20.06.2021.

Paper accepted for publishing on / Дата окончательного согласования работы / Датум коначног прихватања чланка за објављивање: 22.06.2021.

(C) 2021 The Authors. Published by Vojnotehnički glasnik / Military Technical Courier (www.vtg.mod.gov.rs, втг.мо.упр.срб). This article is an open access article distributed under the terms and conditions of the Creative Commons Attribution license (http://creativecommons.org/licenses/by/3.0/rs/)

(c) 2021 Авторы. Опубликовано в «Военно-технический вестник / Vojnotehnički glasnik / Military Technical Courier» (www.vtg.mod.gov.rs, втг.мо.упр.срб). Данная статья в открытом доступе и распространяется в соответствии с лицензией «Creative Commons» (http://creativecommons.org/licenses/by/3.0/rs/)

() 2021 Аутори. Објавио Војнотехнички гласник / Vojnotehnički glasnik / Military Technical Courier (www.vtg.mod.gov.rs, втг.мо.упр.срб). Ово је чланак отвореног приступа и дистрибуира се у складу са Creative Commons licencom (http://creativecommons.org/licenses/by/3.0/rs/). 